\title{
Epidemiologic characteristics and risk factors for renal cell cancer
}

\author{
Loren Lipworth ${ }^{1,2}$ \\ Robert E Tarone ${ }^{1,2}$ \\ Lars Lund ${ }^{2,3}$ \\ Joseph K McLaughlin ${ }^{1,2}$ \\ 'International Epidemiology Institute, \\ Rockville, MD, USA; ${ }^{2}$ Department \\ of Medicine (JKM, RET) and Preventive \\ Medicine (LL), Vanderbilt University \\ Medical Center and Vanderbilt-Ingram \\ Cancer Center, Nashville, TN, USA; \\ ${ }^{3}$ Department of Urology, Viborg \\ Hospital, Viborg, Denmark
}

Correspondence: Loren Lipworth International Epidemiology Institute, I 455 Research Boulevard, Suite 550, Rockville, MD 20850, USA

$\mathrm{Tel}+$ I 30 I 424 I054

Fax + I 30I 424 I053

Email loren@iei.us

\begin{abstract}
Incidence rates of renal cell cancer, which accounts for $85 \%$ of kidney cancers, have been rising in the United States and in most European countries for several decades. Family history is associated with a two- to four-fold increase in risk, but the major forms of inherited predisposition together account for less than $4 \%$ of renal cell cancers. Cigarette smoking, obesity, and hypertension are the most consistently established risk factors. Analgesics have not been convincingly linked with renal cell cancer risk. A reduced risk of renal cell cancer among statin users has been hypothesized but has not been adequately studied. A possible protective effect of fruit and vegetable consumption is the only moderately consistently reported dietary finding, and, with the exception of a positive association with parity, evidence for a role of hormonal or reproductive factors in the etiology of renal cell cancer in humans is limited. A recent hypothesis that moderate levels of alcohol consumption may be protective for renal cell cancer is not strongly supported by epidemiologic results, which are inconsistent with respect to the categories of alcohol consumption and the amount of alcohol intake reportedly associated with decreased risk. For occupational factors, the weight of the evidence does not provide consistent support for the hypotheses that renal cell cancer may be caused by asbestos, gasoline, or trichloroethylene exposure. The established determinants of renal cell cancer, cigarette smoking, obesity, and hypertension, account for less than half of these cancers. Novel epidemiologic approaches, including evaluation of gene-environment interactions and epigenetic mechanisms of inherited and acquired increased risk, are needed to explain the increasing incidence of renal cell cancer.
\end{abstract}

Keywords: renal cell cancer, epidemiology, risk factor, review

\section{Descriptive epidemiology}

Kidney cancer is the ninth most common cancer in developed countries. ${ }^{1}$ Approximately $85 \%$ of kidney cancers are renal parenchyma (renal cell) cancers, while the remainder for the most part are urothelial cancers of the renal pelvis. ${ }^{2}$ Approximately $80 \%$ of renal cell cancers are clear cell adenocarcinomas, the remainder being papillary $(\sim 15 \%)$, chromophobe $(\sim 5 \%)$, and collecting duct carcinomas $(<1 \%)$. Both renal cell and renal pelvis cancers are about twice as common among men as among women, ${ }^{1-3}$ with the mean age at diagnosis in the early $60 \mathrm{~s}$ for renal cell cancer and in the late $60 \mathrm{~s}$ for renal pelvis cancer. For renal pelvis cancer, there is a strong tendency to develop multiple transitional epithelial tumors, particularly in the urinary bladder and ureter. ${ }^{4}$ For the most part, renal pelvis cancer parallels bladder cancer in epidemiologic characteristics and risk factors and has been addressed by the authors elsewhere. ${ }^{4}$

Rates of renal cell cancer vary internationally as much as 10-fold (Table 1), suggesting a strong role for exogenous risk factors in addition to possible roles of geographic differences in genetic susceptibility and diagnostic variability. Incidence is generally highest in several Western and Eastern European countries, as well as in parts of Italy, in North America, and in Australia/New Zealand. The lowest rates are reported in Asia and Africa. How much of this difference is a function of completeness of reporting by country is not clear, but it probably plays a important role. 
Table I International variation in age-adjusted incidence rates (per 100,000 person-years) for renal cell cancer in selected countries

\begin{tabular}{|c|c|c|}
\hline Country & Male & Female \\
\hline Czech Republic & 20 & 10.2 \\
\hline France, Bas-Rhin & 15.6 & 7.3 \\
\hline Iceland & 14.8 & 7.3 \\
\hline Estonia & 14.1 & 7.9 \\
\hline Italy, Florence & 13.7 & 6.6 \\
\hline Slovakia & 12.5 & 5.8 \\
\hline Poland,Warsaw & 12.2 & 5.9 \\
\hline US SEER: black & 12.1 & 6.4 \\
\hline Italy,Venezia & 11.7 & 5 \\
\hline Germany, Saarland & $1 \mathrm{I} .4$ & 6.2 \\
\hline Israel, Jews & 11.2 & 6.1 \\
\hline Finland & 11 & 6.2 \\
\hline Poland, Lower Silesia & 10.1 & 5.7 \\
\hline US SEER: white & 9.6 & 4.9 \\
\hline Canada & 9.5 & 5.2 \\
\hline Australia, New South Wales & 8.7 & 4.6 \\
\hline New Zealand & 8.6 & 4.5 \\
\hline France, Isere & 8.3 & 3.9 \\
\hline Netherlands & 8.2 & 4.6 \\
\hline Norway & 8 & 4.6 \\
\hline Scotland & 7.9 & 4.3 \\
\hline Sweden & 7.8 & 4.8 \\
\hline Denmark & 7.4 & 4.1 \\
\hline UK, England & 6.7 & 3.3 \\
\hline Seoul, Korea & 4.5 & 1.9 \\
\hline Japan, Osaka & 4.4 & 1.5 \\
\hline China, Taiwan & 3.6 & 2.6 \\
\hline Columbia, Cali & 2.9 & 2.3 \\
\hline China, Shanghai & 2.6 & 1.5 \\
\hline Israel, non-Jews & 2.5 & 1.9 \\
\hline Zimbabwe & I.I & 1.6 \\
\hline Uganda & I & I.I \\
\hline
\end{tabular}

Note: Data obtained from Parkin and colleagues.'

Over the past several decades, incidence rates for renal cell cancer have been rising steadily each year in Europe and the United States, ${ }^{5}$ although incidence rates appear to have recently stabilized or decreased in many European countries. ${ }^{6}$ In the United States in 2008, 54,390 new cases and 13,010 deaths were expected from kidney cancer. ${ }^{2}$ A recent report showed that, while the rate of new cancer diagnoses overall dropped $1.8 \%$ among men and $0.5 \%$ among women in the United States between 2001 and 2005, kidney cancer incidence rose $1.7 \%$ per year for males and $2.2 \%$ per year for females. ${ }^{7}$ While there has been a decrease in the size of diagnosed renal cell tumors over time, $, 8,9$ as a result of rapidly improved imaging technology and earlier detection over the last 25 years, an increasing incidence of large and late-stage renal cell cancers has also been observed and accounts in part for the overall increase in incidence. ${ }^{5,9,10}$ In the United States, increases in incidence have been more rapid among women than men ${ }^{11}$ and, in particular, among blacks than whites, ${ }^{10}$ leading to a substantial shift in excess from among whites to among blacks ${ }^{10}$ which is becoming pronounced over time (Figure 1). Age-adjusted incidence rates of renal cell cancer among white men, white women, black men and black women in the United States during 2000-2005 were, respectively, 16.31, $8.03,19.24$, and 8.87 per 100,000 person-years ${ }^{3}$ (Table 2).

Five-year relative survival rates for renal cell cancer in the United States reached $65.1 \%$ among men and $66.8 \%$ among women by $2005,{ }^{3}$ compared with below $40 \%$ in the early $1960 \mathrm{~s}^{10}$ (Table 3). For localized renal cell cancer cases, the fiveyear relative survival rate is approximately $90 \%$, regardless of race or gender. ${ }^{3}$ In Europe, kidney cancer mortality peaked in the early 1990s at 4.8 per 100,000 in men and 2.1 per 100,000 in women, and then declined to 4.1 and 1.8 per 100,000 , respectively, by $2004 .{ }^{6}$ Despite increasing incidence rates, United States kidney cancer mortality rates, which are based on deaths from renal cell cancer as well as cancer of the renal pelvis, have been remarkably stable over the past 15 years, fluctuating between 4.1 and 4.3 per 100,000, suggesting a benefit of early detection and consequent surgical treatment.

\section{Risk factors for renal cell cancer}

Epidemiologic studies for consideration in this review were identified through a MEDLINE ${ }^{\circledR}$ search of the literature. For the purposes of this review, all papers published through 2008 were identified by use of either the term "renal cancer" or the term "kidney cancer" together with the term "risk factor" or "epidemiology." Moreover, all review papers addressing risk factors for kidney cancer in general or renal cell cancer in particular were identified, and references were examined to supplement, if necessary, papers recovered through the initial search. Findings of individual studies were evaluated, and a qualitative summary of the results is presented herein. In the interest of keeping the paper to a reasonable length, we have not attempted to cite every paper that we identified, but rather to emphasize those findings that reflect consistency in the literature.

Information on risk factors for renal cell cancer was established by a large number of case-control studies starting in the 1980s and supported more recently by cohort studies. ${ }^{12-71}$ The largest case-control study to date, based on 1,732 cases and 


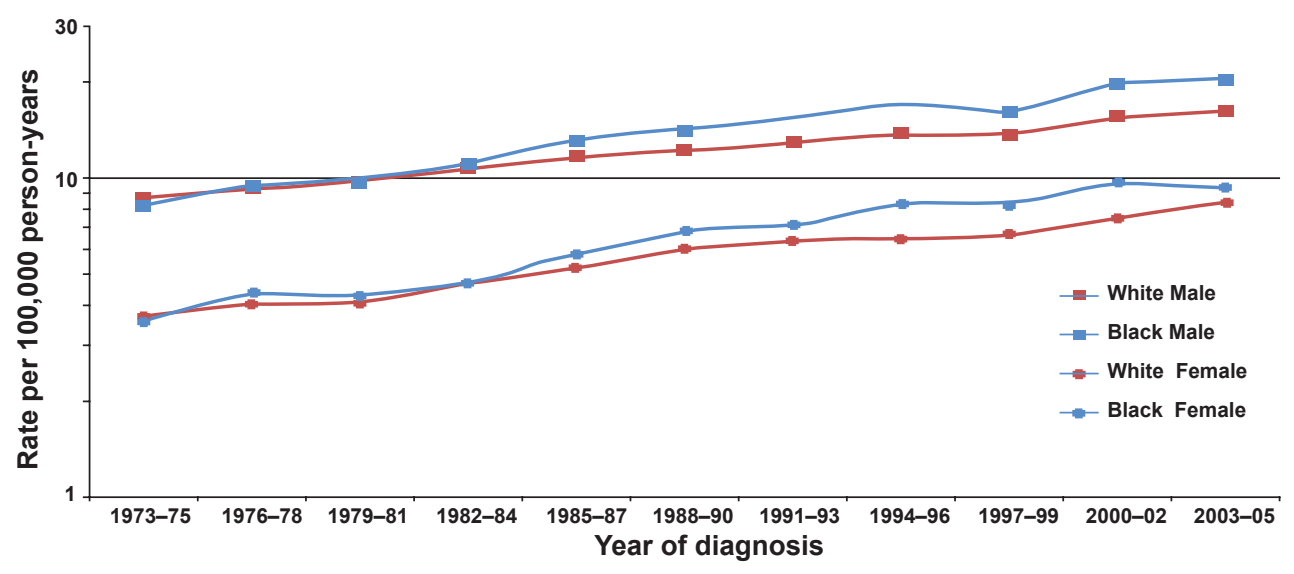

Figure I Trends in age-adjusted (2000 United States standard) incidence of renal cell cancer by race and sex, 1973-2005 (Based on SEER data for nine geographic regions of the United States:Atlanta, Georgia; Connecticut; Detroit, Michigan; Hawaii; lowa; New Mexico; San Francisco/Oakland, California; Seattle/Puget Sound,Washington; and Utah). ${ }^{3}$

2,309 controls, was a multicenter collaborative investigation conducted in five countries using a common protocol, questionnaire, field procedures, and analytic techniques. ${ }^{34,72-78}$ When citing results from this international collaborative investigation, only the combined multicenter results will be reported, not center-specific findings.

\section{Genetic susceptibility}

Renal cell cancer occurs in both sporadic and hereditary forms. Having a first degree relative with kidney cancer has been associated with a two- to four-fold increased risk in most studies. ${ }^{79}$ Hereditary renal cell cancer tends to occur earlier in life than sporadic forms of the disease, and often involves bilateral, multifocal tumors. ${ }^{80}$

Although only about $3 \%-4 \%$ of renal cell cancers are explained by inherited predisposition, ${ }^{80,81}$ it is surprising that no cancer has as many different types of genetic predisposition as renal cell cancer. ${ }^{82}$ Among the rare high-penetrance

Table 2 Age-adjusted incidence rates* for renal parenchyma cancer by racial/ethnic group and sex according to SEER program, 2000 through 2005

\begin{tabular}{lllll}
\hline & No. male & (Rate) & No.female & (Rate) \\
\hline White & 26,195 & 16.31 & 15,345 & 8.03 \\
Black & 3,115 & 19.24 & 1,884 & 8.87 \\
Asian & 1,258 & 7.80 & 731 & 3.67 \\
American Indian & 225 & 12.58 & 159 & 7.67 \\
White non-Hispanic & 22,947 & 16.43 & 13,232 & 7.96 \\
White Hispanic & 3,248 & 15.81 & 2,113 & 8.65
\end{tabular}

Notes: *Per 100,000 person-years, age-adjusted using 2000 United States standard population. Data sourced from SEER Program 17 Registries population, representing $26 \%$ of the United States population. ${ }^{3}$ genetic forms of renal cell cancer are von Hippel-Lindau (VHL) disease (predisposing to clear cell cancer), hereditary papillary carcinoma, hereditary leiomyomatosis and renal cell cancer (papillary), Birt-Hogg-Dubé syndrome (mainly chromophobe and oncocytoma), chromosome 3 translocationassociated (clear cell), tuberous sclerosis (clear cell), and a mutated succinate dehydrogenase (SDHB) gene. ${ }^{80,81}$ In contrast, the only hereditary syndrome with known predisposition to renal pelvis cancer is hereditary nonpolyposis colorectal cancer. ${ }^{80}$ Genetics play a role in renal cell cancer beyond clearly inherited susceptibility, as it has been shown that the majority of noninherited clear cell carcinomas are associated with inactivation of the $V H L$ gene through mutation or promoter hypermethylation. ${ }^{80}$

\section{Obesity}

Renal cell carcinoma is consistently associated with obesity in virtually all epidemiologic studies, including recent large

Table 3 Five-year relative and cause-specific survival rates* for renal parenchyma cancer by race and sex according to SEER program for cases diagnosed from 1990 through 2004

\begin{tabular}{lll}
\hline & \% Male & \% Female \\
\hline \multirow{3}{*}{ White } & Relative survival & \\
Black & 65.1 & 66.8 \\
& 60.0 & 65.0 \\
White & Cause-specific survival & \\
Black & 67.7 & 69.6 \\
\hline
\end{tabular}

Notes: *Percentage of cases surviving five years after diagnosis of a first primary cancer in the renal parenchyma. Data sourced from SEER Program 17 Registries Population, representing $26 \%$ of the United States population. ${ }^{3}$ 
prospective studies in the Netherlands, Norway, and the United States. ${ }^{59,60,62,65,70,71,78,83-85}$ Most studies have found an association with elevated body mass index (BMI) among both men and women, and abdominal obesity, as indicated by waist-to-hip ratio, ${ }^{58,65,70,71,85}$ may play an important role in this association, particularly among women. A quantitative review of the published literature reported a summary relative risk for renal cell cancer of 1.07 per unit increase of BMI. ${ }^{83}$ A more recent meta-analysis reported that associations with increased BMI were stronger in women than in men; summary risk ratios per $5 \mathrm{~kg} / \mathrm{m}^{2}$ increase in BMI were 1.24 (95\% confidence interval [CI] 1.15-1.34) among men and 1.34 (95\% CI 1.25-1.43) among women. ${ }^{86}$

Several plausible mechanisms have been suggested for the association between obesity and renal cell cancer, but the actual mechanism remains speculative. Obesity may promote changes in circulating levels of estrogen and other steroid hormones, or elevated levels of insulin-like growth factor-I (IGF-I), which could in turn contribute to the development of renal cell cancer ${ }^{87-90}$ Lipid peroxidation, which is increased among obese subjects, has been hypothesized to be partly responsible for the association of obesity with renal cell cancer through the formation of DNA adducts. ${ }^{91}$ Other conjectured mechanisms include elevated cholesterol level and down-regulation of low-density lipoprotein receptor, lower levels of vitamin D, and increases in adipose tissue-derived hormones and cytokines, such as leptin and adiponectin..$^{84,92,93}$

The increasing prevalence of obesity, rapidly becoming a worldwide epidemic, ${ }^{93-95}$ is likely to account in part for the rising incidence of renal cell cancer. Recent calculations suggest the proportion of renal cell cancer attributable to being overweight and obese could be as high as $40 \%$ in the United States and Canada and $30 \%$ in Europe. . $^{83,87,93,96,97}$

\section{Cigarette smoking}

Cigarette smoking is a recognized though moderate cause of renal cell cancer. ${ }^{98}$ A recent meta-analysis ${ }^{99}$ of data from 19 case-control studies (8,032 cases and 13,800 controls) and five cohort studies $(1,457,754$ participants with 1,326 renal cell cancer cases) reports statistically significant relative risks of 1.5 and 1.2 for male and female smokers, respectively. There was a strong dose-dependent increase in risk, up to 2- and 1.6-fold among heavy ( 21 or more cigarettes per day) men and women smokers, respectively. There was a significant decline in risk in both sexes with years of cessation, with a $15 \%$ to $30 \%$ reduction in risk 10 to 15 years after quitting. ${ }^{99}$ Approximately $20 \%$ to $30 \%$ of renal cell cancers among men and $10 \%$ to $20 \%$ among women are estimated to be attributable to cigarette smoking. ${ }^{34,100,101}$

\section{Hypertension and antihypertensive medications}

The recent increases in renal cell cancer incidence may be associated, again in an unknown way, with the increasing prevalence of hypertension in the United States, particularly among blacks and among women. ${ }^{101,102}$ While it is difficult to separate the effects of hypertension or its treatment on renal cell cancer risk, as they are highly correlated variables, the collective epidemiologic evidence to date suggests that it is hypertension itself that is the determinant. Most studies have reported risks for renal cell cancer associated with either recorded blood pressure or reported hypertension ranging between 1.2 and 2 or greater, ${ }^{48,51,54-56,62,68,69,72,103-106}$ although not all of the studies were able to adjust for the effect of antihypertensive medications. Dose-response relations between measured blood pressure level and renal cell cancer risk have been reported, ${ }^{54,56,106}$ although only one of these studies provided data on women and considered the effect of antihypertensive medication. ${ }^{106}$ In that analysis of 254,935 men and women in the European Prospective Investigation into Cancer and Nutrition (EPIC), the relative risks for the highest versus the lowest category of systolic ( $\geq 160 \mathrm{vs}<120 \mathrm{mmHg}$ ) and diastolic ( $\geq 100 \mathrm{vs}<80 \mathrm{mmHg}$ ) blood pressure were 2.48 (95\% CI 1.53-4.02) and 2.34 (95\% CI 1.54-3.55), respectively, independent of use of antihypertensive medication. A case-control study reported that high systolic and diastolic blood pressures were independently associated with increased renal cell cancer risk in both sexes when analyses were restricted to those who never took antihypertensive medication. ${ }^{103}$ Several ${ }^{55-57,63,106}$ cohort studies have demonstrated an increased risk even after exclusion of the early years of follow-up, when early stage, prediagnostic renal tumors may themselves lead to elevated blood pressure. Recent findings from the Netherlands cohort study ${ }^{105}$ suggest that the association with hypertension may be stronger among the small fraction of sporadic renal cell cancer patients with von Hippel-Lindau gene mutations, but this needs to be confirmed in future studies.

Most epidemiologic studies of antihypertensive drugs and renal cell cancer risk have found that diuretic use, a causal factor candidate in early studies, is not an independent risk factor, and adjustment for high blood pressure appears to eliminate any excess risk associated with diuretic use. ${ }^{48,62,72,103}$ In a study of the various classes of antihypertensive medications, no particular type or class of 
these medications was consistently associated with renal cell cancer risk. ${ }^{107}$

The biologic mechanism for the association between high blood pressure and renal cell cancer risk is unknown. Among the candidate hypotheses regarding mechanism has been hypertension-induced renal injury and metabolic or functional changes within the renal tubule induced by hypertension increasing susceptibility to carcinogens. It has also been speculated that elevated levels of IGF-I or lipid peroxidation associated with hypertension, as well as up-regulation of hypoxia-inducible factors, could contribute to the development of renal cell cancer. Contrary to expectation, detection bias due to incidental diagnosis during work-ups for hypertension was not supported in a study which directly evaluated that hypothesis. ${ }^{108}$

\section{Analgesics}

Historically, the causal connection of heavy use and abuse of phenacetin-containing analgesics and transitional cell cancers of the renal pelvis has long been recognized. Phenacetin's effect on adenocarcinomas of the renal parenchyma, however, is inconclusive, ${ }^{27,28,109}$ and it is now impossible to assess because phenacetin-containing analgesics have been off the market for up to 30 years in most countries and reliable recall of past intake is no longer achievable.

Among other analgesics, acetaminophen has received the most attention, since it is the major metabolite of phenacetin, although several studies have also examined the effect of aspirin use on renal cell cancer. ${ }^{21,73,109-113}$ Neither acetaminophen nor aspirin has been credibly associated with an increase in renal cell cancer risk. ${ }^{73,111}$

\section{Statins}

Statins are widely used drugs for the treatment of lipid disorders, particularly hypercholesterolemia. Despite reported antitumorigenic activity of statins, including their inhibition of proliferation and promotion of apoptosis, their potential effectiveness for the primary prevention of cancer remains to be reliably demonstrated. While some observational studies have reported inverse associations with cancer, neither the Cholesterol Treatment Trialists' (CTT) Collaboration ${ }^{114}$ nor two recent meta-analyses ${ }^{115,116}$ found evidence of an effect of statin therapy on cancer risk. A study based on Veteran Affair (VA) databases in the United States reported a 50\% reduced risk of renal cell carcinoma among statin users compared with nonusers. ${ }^{17}$ This finding may be influenced by selection bias, however, since the controls were drawn from frequent users of the VA system who might be more likely to be prescribed statins. Furthermore, the study did not address the influence of dose, duration, and type of statin in relation to renal cell cancer risk. There is some evidence that only lipophilic statins, such as simvastatin and lovastatin, possess antineoplastic effects, whereas hydrophilic statins, such as pravastatin, do not have chemopreventive potential. ${ }^{118,119}$ Other epidemiological studies reporting on the association of statin use and urologic cancers have yielded inconsistent results, ${ }^{119-125}$ however, only combined results for kidney and bladder cancer were presented in many of these studies. A follow-up study of 361,859 statin users, most of whom received lovastatin or simvastatin, found a non-significantly increased risk of kidney/renal pelvis cancer. ${ }^{125}$ Two casecontrol studies reported no association between current or regular statin use and kidney cancer. ${ }^{121,123}$ Most published studies on statin use had relatively short follow-up and reported for the most part only on the most common cancer types. Further research is warranted to investigate the association between use of statins and any potential increase or decrease in risk of renal cell cancer, with particular focus on duration, intensity, and type and dose of statin used.

\section{Dietary factors}

Renal cell cancer has not been convincingly linked to any specific dietary factor, with the exception of a moderately consistent protective effect for overall fruit and vegetable consumption. ${ }^{61,126-130}$ However, two recent large prospective studies, one based on 375,851 participants in the EPIC study ${ }^{131}$ and the other based on 120,852 men and women in the Netherlands Cohort Study on Diet and Cancer (NLCS), ${ }^{132}$ reported no protective effect of vegetable and/or fruit consumption on renal cell cancer. Some epidemiologic studies suggest that elevated protein consumption may be a risk factor for renal cell cancer. There may be some biologic plausibility to a high protein diet affecting risk of renal cell cancer, because animal studies have shown protein intake can induce renal tubular hypertrophy, but the largest study to date to evaluate this association failed to provide clear support for this hypothesis, ${ }^{78}$ as has a large, pooled analysis of 13 cohort studies. ${ }^{133}$

Elevated risks have been reported for consumption of meat, ${ }^{16,24,27,28,47,128}$ milk, ${ }^{21,25}$ and margarine, oils and other fat types; ${ }^{25,47}$ however, most of these findings were not adjusted for confounding by energy intake. Sporadic inverse associations have been reported with respect to vitamin $\mathrm{C},{ }^{47}$ Vitamin E, ${ }^{78,128}$ carotenoids, ${ }^{127}$ and calcium, ${ }^{128}$ but no particular micronutrient or vitamin has been consistently observed to decrease or increase the risk of renal cell cancer in case-control 
or cohort studies. Although originally thought almost 30 years ago to be a key area for renal cell cancer causation, dietary studies have not fulfilled their early promise.

\section{Alcohol consumption}

Early ecologic studies consistently suggested a positive correlation between kidney cancer and per capita consumption of alcohol. ${ }^{134-136}$ However, these ecologic findings were not confirmed by numerous analytic epidemiologic studies of renal cell cancer conducted during the ensuing two decades. ${ }^{4,66}$ After adjustment for the confounding effect of cigarette use, virtually all studies showed no association between alcohol consumption and renal cell cancer. ${ }^{16-20,24,25,27,28,30,78}$ Cohort studies of alcoholics and brewery workers have also reported no excess of mortality from kidney cancer. ${ }^{137-142}$

By contrast, a post hoc hypothesis has recently appeared in the literature that moderate levels of alcohol consumption may be protective for renal cell cancer. The findings of recent individual studies show considerable heterogeneity and inconsistency with respect to the categories of alcohol consumption, the amount of alcohol intake reportedly associated with decreased renal cell cancer risk, and differential observations between men and women. A pooled analysis of data from 12 prospective studies of renal cell cancer was recently published, based on results of five published studies $^{58,143-145}$ as well as numerous others which had not previously published their data related to alcohol consumption. ${ }^{146}$ The pooled analysis was based on 1430 incident cases of renal cell cancer (719 men and 711 women), and demonstrated an apparent inverse-response relation at levels of consumption equivalent to less than a drink per day, with no further protective effect at levels of intake above a drink a day. It is difficult to speculate what biologic mechanism could explain this type of dose-response pattern, unless of course one invokes a hormesis-like effect of low-dose alcohol on renal cancer risk while other organs seemingly do not enjoy this anticarcinogenic effect.

Finally, alcohol itself is a known human carcinogen and heavy alcohol drinking has been conclusively linked to increased risks of numerous types of cancer, including oral, pharyngeal, laryngeal, esophageal, liver and probably breast and colon and rectum. ${ }^{147}$ A protective effect of alcohol consumption on renal cell cancer at very low levels of intake has little biologic plausibility or face validity. In addition to the extensive analytic epidemiologic evidence from the past 40 years, the descriptive patterns of renal cell carcinoma are not consistent with an inverse association with alcohol intake. In particular, the rate of renal cell carcinoma among men is twice that among women worldwide, whereas men tend to consume alcohol at substantially higher levels than women.

\section{Hormonal and reproductive factors}

Reductions in risk of renal cell cancer have been reported among users of oral contraceptives in some, ${ }^{76,148}$ but not all studies, ${ }^{149,150}$ and in the large international case-control study protection was restricted to nonsmokers. ${ }^{76}$ Several studies have reported an almost two-fold increased risk among women with high parity compared with nulliparous women, after adjustment for obesity, ${ }^{76,148,151}$ and an inverse association between age at first birth and risk of renal cell cancer has been reported in some ${ }^{28,39,149,151}$ but not all studies. ${ }^{148,150}$ Hormones have induced renal tumors in laboratory animals; however, with the exception of a positive association with parity, evidence for a role of hormonal or reproductive factors in the etiology of renal cell cancer in humans is limited and not entirely consistent to date.

\section{Occupation}

As compared with bladder cancer, renal cell cancer has not been convincingly linked to any occupational exposure. ${ }^{4}$ However, because of the large number of epidemiologic studies, particularly case-control studies, that have been conducted over the last three decades, a number of sporadic associations have been reported between exposures or jobs/industries and renal cell cancer. Asbestos has been associated with elevated renal cancer mortality in two cohort studies, one of insulators ${ }^{152}$ and one of asbestos products workers, ${ }^{153}$ as has self-reported asbestos exposure in several case-control studies, including the large international study. ${ }^{75}$ An extensive meta-analysis of occupational cohort studies of asbestos-exposed workers showed little relation to increased risk for renal cancer. ${ }^{154}$

In the early 1980s, unleaded gasoline was suspected as a risk factor for renal cell cancer based on long-term rodent bioassays in which male rats developed renal tumors. Since then, a number of occupational cohort and nested case-control studies have examined the effect of gasoline exposure in numerous populations, and the collective evidence to date does not support a relation between gasoline and risk of renal cell cancer ${ }^{155-165}$ Further, the mechanism by which male rats developed kidney cancer when exposed to unleaded gasoline vapors, via a unique protein molecule, alpha2 microglobulin, has no counterpart in humans. ${ }^{156,166}$

In recent years, considerable attention has focused on the solvent trichloroethylene (TCE), largely as a result of 
animal findings and of three epidemiologic studies conducted in one area of Germany, initiated in response to a cluster of renal cell cancer cases observed in a plant. All three of these studies reported strikingly elevated relative risks for renal cell cancer associated with TCE exposure. ${ }^{167-169}$ The findings contrast starkly with results from other investigations, and several serious methodological shortcomings of these studies have been noted, ${ }^{170-172}$ limiting any conclusion that can be drawn. To date, seven occupational cohort studies have evaluated the relationship between TCE exposure and specific types of cancer. The two largest employed sophisticated methods of exposure assessment and both internal and external comparisons. ${ }^{173,174}$ Neither of these studies reported a significantly increased risk of renal cell cancer among TCE-exposed workers. The most recent cohort study, ${ }^{175}$ conducted in Denmark, evaluated cancer incidence among 40,049 workers with presumed TCE exposure and found a weak association with renal cell cancer among those thought to be heavily exposed to TCE. The weight of the evidence to date, however, does not provide consistent, credible support for the hypothesis that TCE is a cause of renal cell cancer in humans. ${ }^{176}$ Whether TCE is a renal carcinogen in humans remains an open question, which will require more and better research.

A German study reported that $V H L$ mutations were found in 33 of 44 RCC patients from North Rhine-Westphalia with TCE exposure. ${ }^{177,178}$ Of the 33 patients with VHL mutations, 14 had multiple VHL mutations and remarkably, 13 had the same $\mathrm{C}$ to $\mathrm{T}$ substitution in codon $81 .{ }^{177}$ Two subsequent studies could not confirm either the tendency towards multiple $V H L$ mutations or the $V H L$ codon 81 mutation hot spot in TCE-exposed RCC patients from Germany and France. ${ }^{179,180}$ In view of the widespread use of TCE around the world, it is noteworthy that among approximately $600 \mathrm{VHL}$ mutations reported in sporadic RCC patients from other published studies (predominately of western European patients), only one other $\mathrm{C}$ to $\mathrm{T}$ substitution in codon 81 has been reported. ${ }^{181}$ This suggests that the VHL mutation hot spot in the German study resulted from either a unique TCE exposure situation in a restricted geographic area or some other environmental exposure prevalent in that geographic area. If the $V H L$ codon 81 mutation hot spot is a marker for TCE-induced RCC, then the overall findings suggest that TCE is not a major contributor to the global RCC burden.

\section{Kidney transplantation and dialysis}

Acquired renal cystic disease of the native kidneys is believed to account for the substantially higher average annual incidence of renal cell carcinoma in dialysis patients, independent of patient age or underlying renal disease. ${ }^{182,183}$ Several recent studies of cancer risk subsequent to kidney transplantation have found a substantially increased risk of acquired renal cystic disease and renal cell cancer compared with the general population, presumed to be a result of immune-suppressing medications used in transplant patients. $^{184}$

\section{Summary}

To date, the causal determinants identified for renal cell cancer in epidemiologic studies, cigarette smoking, obesity, and hypertension, are at best moderate in their effect on risk and account for less than half of these cancers. Major, explanatory causes of renal cell cancer await novel epidemiologic approaches, including more sophisticated genetic studies. Because single-gene determinants of renal cell cancer have been thoroughly investigated for almost 30 years with at best very limited success, future investigations should examine more complex genetic associations, including gene-environment interactions and epigenetic mechanisms of inherited and acquired increased risk.

\section{Acknowledgments}

This paper is dedicated to the memory of Dr Edward Lipworth (1910-2009) a leading urologist in both South Africa and Israel whose lifelong passion for learning and helping mankind extended almost an entire century.

\section{Disclosure}

The authors report no conflicts of interest in this work.

\section{References}

1. Parkin CM, Whelan SL, Ferlay J, Teppo L, Thomas D. Cancer Incidence in Five Continents, Volume VIII. IARC Scientific Publications No. 155. Lyon, France: International Agency for Research on Cancer, 2002.

2. Jemal A, Siegel R, Ward E, et al. Cancer statistics, 2008. Ca Cancer J Clin. 2008;58:71-96.

3. National Cancer Institute. DCCPS, Surveillance Research Program, Cancer Statistics Branch. SEER Program 17 Registries Public Use Tapes (1973-2005, varying), November 2007 Submission, Released April 2008.

4. McLaughlin JK, Lipworth L, Tarone RE, Blot WJ. Renal cancer. In: Schottenfeld D, Fraumeni JF Jr, editors. Cancer Epidemiology and Prevention, Third Edition. New York, NY: Oxford University Press; 2006. p. 1087-1100.

5. Mathew A, Devesa SS, Fraumeni JF Jr, Chow WH. Global increases in kidney cancer incidence, 1973-1992. Eur J Cancer Prev. 2002;11: 171-178.

6. Levi F, Ferlay J, Galeone C, et al. The changing pattern of kidney cancer incidence and mortality in Europe. BJU Int. 2008;101:949-958.

7. Jemal A, Thun MJ, Ries LAG, et al. Annual report to the nation on the status of cancer, 1975-2005, featuring trends in lung cancer, tobacco use, and tobacco control. J Natl Cancer Inst. 2008;100:1672-1694. 
8. Nguyen MM, Gill IS, Ellison LM. The evolving presentation of renal carcinoma in the United States: trends of the Surveillance, Epidemiology, and End Results Program. J Urol. 2006;176:2397-2400.

9. Hollingsworth JM, Miller DC, Daignault S, Hollenbeck BK. Rising incidence of small renal masses: a need to reassess treatment effect. J Natl Cancer Inst. 2006;98:1331-1334.

10. Kosary CL, McLaughlin JK. Kidney and renal pelvis, in Miller BA, Ries LAG, Hankey BE (eds): Cancer Statistics Review: 1973-1990. National Cancer Institute. NIH Pub. No. 93-2789, 1993, X1-X22.

11. Chow WH, Devesa SS, Warren JL, et al. The rising incidence of renal cell cancer in the United States. JAMA. 1999;281:1628-1631.

12. Bennington JL, Laubscher FA. Epidemiologic studies of carcinoma of the kidney. I. Association of renal adenocarcinoma with smoking. Cancer. 1968;21:1069-1071.

13. Wynder EL, Mabuchi K, Whitemore WF. Epidemiology of adenocarcinoma of the kidney. J Natl Cancer Inst. 197453:1619-1634.

14. Armstrong B, Garrod A, Doll R. A retrospective study of renal cancer with special reference to coffee and animal protein consumption. $\mathrm{Br} J$ Cancer. 1976;33:127-136.

15. Kolonel LN. Association of cadmium with renal cancer. Cancer. 1976;37:1782-1787.

16. McLaughlin JK, Mandel JS, Blot WJ, Schuman LM, Mehl ES, Fraumeni JF Jr. Population-based case-control study of renal cell carcinoma. $J$ Natl Cancer Inst. 1984;72:275-284.

17. Yu MC, Mack TM, Hanesch R, Cicioni C, Henderson BE. Cigarette smoking, obesity, diuretic use, and coffee consumption as risk factors for renal cell carcinoma. J Natl Cancer Inst. 1986;77:351-356.

18. Goodman MT, Morgenstern H, Wynder EL. A case-control study of factors affecting the development of renal cell cancer. Am J Epidemiol. 1986;124:926-941.

19. Brownson RC. A case-control study of renal cell carcinoma in relation to occupation, smoking, and alcohol consumption. Arch Environ Health. 1988;43:238-241.

20. Asal NR, Risser DR, Kadamani S, et al. Risk factors in renal cell carcinoma. I. Methodology, demographics, tobacco, beverage use, and obesity. Cancer Detect Prev. 1988;11:359-377.

21. McCredie M, Ford JM, Stewart JH. Risk factors for cancer of the renal parenchyma. Int J Cancer. 1988;42:13-16.

22. Sharpe CR, Rochon JE, Adam JM, et al. Case-control study of hydrocarbon exposures in patients with renal cell carcinoma. Can Med Assoc J. 1989;140:1309-1318.

23. La Vecchia C, Negri E, D'Avanzo B, et al. Smoking and renal cell carcinoma. Cancer Res. 1990;50:5231-5233.

24. Maclure M, Willett W. A case-control study of diet and risk of renal adenocarcinoma. Epidemiology. 1990;1:430-440.

25. Talamini R, Barón AE, Barra S, et al. A case-control study of risk factors for renal cell cancer in northern Italy. Cancer Causes Control. 1990;1:125-131.

26. Partanen T, Heikkila P, Hernberg S, et al. Renal cell cancer and occupational exposure to chemical agents. Scand J Work Environ Health. 1991;17:231-239.

27. McLaughlin JK, Gao YT, Gao RN, et al: Risk factors for renal cell cancer in Shanghai, China. Int J Cancer. 1992;52:562-565.

28. Kreiger N, Marrett LD, Dodds L, et al. Risk factors for renal cell carcinoma: results of a population-based case-control study. Cancer Causes Control. 1993;4:101-110.

29. Finkle WD, McLaughlin JK, Rasgon SA, et al. Increased risk of renal cell cancer among women using diuretics in the United States. Cancer Causes Control. 1993;4:555-558.

30. Benhamou S, Lenfant M-H, Ory-Paoletti C, et al. Risk factors for renal cell carcinoma in a French case-control study. Int J Cancer. 1993;55:32-36.

31. Hiatt RA, Tolan K, Quesenberg CP. Renal cell carcinoma and thiazide use: a historical case-control study. Cancer Causes Control. 1994;5: 319-325.

32. Weinmann S, Glass AG, Weiss NS, et al. Use of diuretics and other antihypertensive medications in relation to the risk of renal cell cancer. Am J Epidemiol. 1994;140:792-804.
33. Muscat JE, Hoffmnn D, Wynder EL. The epidemiology of renal cell carcinoma: a second look. Cancer. 1995;75:2552-2557.

34. McLaughlin JK, Lindblad P, Mellemgaard A, et al. International renalcell cancer study. I. Tobacco use. Int J Cancer. 1995;60:194-198.

35. McCredie M, Stewart JH. Risk factors for kidney cancer in New South Wales: I. Cigarette smoking. Eur J Cancer. 1992;28A:2050-2054.

36. McCredie M, Stewart JH. Risk factors for kidney cancer in New South Wales. II. Urological disease, hypertension, obesity and hormonal factors. Cancer Causes Control. 1992;3:323-331.

37. Mellemgaard A, Engholm G, McLaughlin JK, et al. Risk of renal cell carcinoma in Denmark. I. Role of socioeconomic status, tobacco use, beverages, and family history. Cancer Causes Control. 1994;5:105-113.

38. Mellemgaard A, Niwa S, Mehl ES, et al. Risk factors for renal cell carcinoma in Denmark. II. Role of medication and medical history. Int J Epidemiol. 1994;23:923-930.

39. Mellemgaard A, Engholm G, McLaughlin JK, et al. Risk of renal cell carcinoma in Denmark. III. Role of weight, physical activity, and reproductive factors. Int J Cancer. 1994;56:66-71.

40. Mellemgaard A, Engholm G, McLaughlin JK, et al. Occupational risk factors for renal cell carcinoma in Denmark. Scand J Work Environ Health. 1994;20:160-165.

41. Chow WH, McLaughlin JK, Linet MS, et al. Use of analgesics and risk of renal cell cancer. Int J Cancer. 1994;59:467-470.

42. Chow WH, Gridley G, McLaughlin JK, et al. Protein intake and risk of renal cell cancer. J Natl Cancer Inst. 1994;86:1131-1139.

43. Chow WH, McLaughlin JK, Mandel JS, et al. Obesity and risk of renal cell cancer. Cancer Epidemiol Biomarkers Prev. 1996;5:17-21.

44. Schlehofer B, Heuer C, Blettner M, et al. Occupation, smoking and demographic factors, and renal cell carcinoma in Germany. Int $J$ Epidemiol. 1995;24:51-57.

45. Lindblad P, Wolk A, Bergstrom A, et al. The role of obesity and weight fluctuations in the etiology of renal cell cancer: a population-based casecontrol study. Cancer Epidemiol Biomarkers Prev. 1994;3:631-639.

46. Lindblad P, Wolk A, Bergstrom R, et al. Diet and risk of renal cell cancer: a population-based case-control study. Cancer Epidemiol Biomarkers Prev. 1997;6:215-223.

47. Boeing H, Schlehofer B, Wahrendorf J. Diet, obesity and risk for renal cell carcinoma: results from a case-control study in Germany. Z Ernahrungswiss. 1997;36:3-11

48. Yuan JM, Castelao JE, Gago-Dominguez M, et al. Hypertension, obesity and their medications in relation to renal cell carcinoma. Br J Cancer. 1998;77:1508-1513.

49. Bianchi GD, Cerhan JR, Parker AS, et al. Tea consumption and risk of bladder and kidney cancers in a population-based case-control study. Am J Epidemiol. 2000;151:377-383.

50. Pesch B, Haerting J, Ranft U, et al. Occupational risk factors for renal cell carcinoma: agent-specific results from a case-control study in Germany. MURC Study Group. Multicenter urothelial and renal cancer study. Int J Epidemiol. 2000;29:1014-1024.

51. Semenza JC, Ziogas A, Largent J, et al. Gene-environment interactions in renal cell carcinoma. Am J Epidemiol. 2001;153:851-859.

52. Hu J, Mao Y, White K, et al. Overweight and obesity in adults and risk of renal cell carcinoma in Canada. Soz Praventivmed. 2003;48:178-185.

53. McLaughlin JK, Hrubec Z, Heineman EF, et al. Renal cancer and cigarette smoking in a 26-year followup of US veterans. Public Health Rep. 1990;105:535-537.

54. Coughlin SS, Neaton JD, Randall B, et al. Predictors of mortality from kidney cancer in 332,547 men screened for the Multiple Risk Factor Intervention Trial. Cancer. 1997;79:2171-2177.

55. Heath CW Jr, Lally CA, Calle EE, et al. Hypertension, diuretics, and antihypertensive medications as possible risk factors for renal cell cancer. Am J Epidemiol. 1997;145:607-613.

56. Chow WH, Gridley G, Fraumeni JR Jr, et al. Obesity, hypertension, and the risk of kidney cancer in men. N Engl J Med. 2000;343:1305-1311.

57. Mahabir S, Leitzmann MK, Pietinen P, et al. Physical activity and renal cell cancer risk in a cohort of male smokers. Int $J$ Cancer. 2004;108:600-605. 
58. Nicodemus KK, Sweeney C, Folsom AR. Evaluation of dietary, medical and lifestyle risk factors for incident kidney cancer in postmenopausal women. Int J Cancer. 2004;108:115-121.

59. Van Dijk BAC, Schouten LJ, Kiemeney LALM, et al. Relation of height, body mass, energy intake, and physical activity to risk of renal cell carcinoma: results from the Netherlands Cohort Study. Am J Epidemiol. 2004;160:1159-1167.

60. Bjorge T, Tretli S, Engelend A. Relation of height and body mass index to renal cell carcinoma in two million Norwegian men and women Am J Epidemiol. 2004;160:1168-1176.

61. Rashidkhani B, Lindblad P, Wolk A. Fruits, vegetables and risk of renal cell carcinoma: a prospective study of Swedish women. Int $J$ Cancer. 2005; 113:451-455.

62. Flaherty KT, Fuchs CS, Colditz GA, et al. A prospective study of body mass index, hypertension, and smoking and the risk of renal cell carcinoma (United States). Cancer Causes Control. 2005;16:1099-1106.

63. Choi MY, Jee SH, Sull JW, et al. The effect of hypertension on the risk for kidney cancer in Korean men. Kidney Int. 2005;67:647-652.

64. Lindgren AM, Nissinen AM, Tuomilehto JO, et al. Cancer pattern among hypertensive patients in North Karelia, Finland. J Hum Hypertens. 2005;19:373-379.

65. Pischon T, Lahmann PH, Boeing H, et al. Body size and risk of renal cell carcinoma in the European Prospective Investigation into Cancer and Nutrition. Int J Cancer. 2006;118:728-738.

66. Lipworth L, Tarone RE, McLaughlin JK. The epidemiology of renal cell carcinoma. J Urol. 2006;176;2353-2358.

67. McLaughlin JK, Lipworth L, Tarone RE. Epidemiologic aspects of renal cell carcinoma. Semin Oncol. 2006;33:527-533.

68. Zucchetto A, Dal Maso L, Tavani A, et al. History of treated hypertension and diabetes mellitus and risk of renal cell cancer. Ann Oncol. 2007;18:596-600.

69. Brennan P, van der Hel O, Moore LE, et al. Tobacco smoking, body mass index, hypertension and kidney cancer risk in central and eastern Europe. Br J Cancer. 2008;99:1912-1915.

70. Adams KF, Leitzmann MF, Albanes D, et al. Body size and renal cell cancer incidence in a large US cohort study. Am J Epidemiol. 2008; 168:268-277.

71. Luo J, Margolis KL, Adami HO, Lopez AM, Lessin L, Ye W. Body size, weight cycling, and risk of renal cell carcinoma among postmenopausal women: the Women's Health Initiative (United States). Am J Epidemiol. 2007;166:752-759.

72. McLaughlin JK, Chow WH, Mandel JS, et al. International renal-cell cancer study. VIII. Role of diuretics, other anti-hypertensive medications and hypertension. Int J Cancer. 1995;63:216-221.

73. McCredie M, Pommer W, McLaughlin JK, et al. International renal cell cancer study. II. Analgesics. Int J Cancer. 1995;60:345-349.

74. Mellemgaard A, Odaka N, Lindblad P, et al. International renal-cell cancer study. III. Role of weight, height, physical activity and use of amphetamines. Int J Cancer. 1995;60:350-354.

75. Mandel JS, McLaughlin JK, Schlehofer B, et al. International renal-cell cancer study. IV. Occupation. Int J Cancer. 1995;61:601-605.

76. Lindblad P, Chow WH, Chan J, et al. International renal-cell cancer study. V. Reproductive factors, gynecologic operations and exogenous hormones. Int J Cancer. 1995;61:192-198.

77. Schlehofer B, Pommer W, Mellemgaard A, et al. International renal-cell cancer study. VI. The role of medical and family history. Int J Cancer. 1996;66:723-726.

78. Wolk A, Gridley G, Niwa S, et al. International renal-cell cancer study. VII. Role of diet. Int J Cancer. 1996;65:67-73.

79. Noordzij MA, Mickisch GH. The genetic make-up of renal cell tumors. Urol Res. 2004;32:251-254.

80. Choyke PL, Glenn GM, Walther MM, Zbar B, Linehan WM. Hereditary renal cancers. Radiology. 2003;226:33-46.

81. Ricketts C, Woodward ER, Killick P, et al. Germline SDHB mutations and familial renal cell carcinoma. J Natl Cancer Inst. 2008;100:1260-1262.

82. Cohen HT, McGovern FJ. Renal cell carcinoma. $N$ Eng $J$ Med. 2005;353:2477-2490.
83. Bergstrom A, Hsieh CC, Lindblad P, et al. Obesity and renal cell cancer - a quantitative review. Br J Cancer. 2001;85:984-990.

84. Pan SY, DesMeules M, Morrison H, Wen SW, and The Canadian Cancer Registries Epidemiology Group. Obesity, high energy intake, lack of physical activity and the risk of kidney cancer. Cancer Epidemiol Biomarkers Prev. 2006;15:2453-2460.

85. Dal Maso L, Zucchetto A, Tavani A, et al. Renal cell cancer and body size at different ages: an Italian multicenter case-control study. Am J Epidemiol. 2007; 166:582-591.

86. Renehan AG, Tyson M, Egger M, Heller RF, Zwahlen M. Body mass index and incidence of cancer: a systematic review and meta-analysis of prospective observational studies. Lancet. 2008;371:569-578.

87. Calle EE, Kaaks R. Overweight, obesity and cancer: epidemiological evidence and proposed mechanisms. Nature Rev Cancer. 2004; 4:579-591.

88. Yu H, Rohan T. Role of the insulin-like growth factor family in cancer development and progression. J Natl Cancer Inst. 2000;92:1472-1489.

89. Frystyk J, Vestbo E, Skjaebaek C, et al. Free insulin-like growth factors in human obesity. Metabolism. 1995;44:37-44.

90. Kellerer M, von Eye CH, Muhlhofer A, et al. Insulin- and insulin-like growth-factor-I receptor tyrosine-kinase activities in human renal carcinoma. Int J Cancer. 1995;62:501-507.

91. Gago-Dominguez M, Castelao JE, Yuan JM, et al. Lipid peroxidation: a novel and unifying concept of the etiology of renal cell carcinoma (United States). Cancer Causes Control. 2002;13:287-293.

92. Moyad MA. Obesity, interrelated mechanisms, and exposures and kidney cancer. Semin Urol Oncol. 2001;19:270-279.

93. Pischon T, Nothlings U, Boeing H. Obesity and cancer. Proc Nutr Soc. 2008;67:128-145.

94. Flegal KM, Carroll MD, Ogden CL, Johnson CL. Prevalence trends in obesity among US adults, 1999-2000. JAMA. 2002;288:1723-1727.

95. WHO. Obesity: preventing and managing the global epidemic. Report of a $\mathrm{HO}$ consultation on obesity. WHO technical report series (no. 894). Geneva, Switzerland: World Health Organization; 2000.

96. Pan SY, Johnson KC, Ugnat AM, et al. Association of obesty and cancer risk in Canada. Am J Epidemiol. 2004;159:259-268.

97. Bergstrom A, Pisani P, Tenet V, et al. Overweight as an avoidable cause of cancer in Europe. Int J Cancer. 2001;91:421-430.

98. Vineis $\mathrm{P}$, Alavanja $\mathrm{M}$, Buffler $\mathrm{P}$, et al. Tobacco and cancer: recent epidemiological evidence. J Natl Cancer Inst. 2004;96:99-106.

99. Hunt JD, van der Hel OL, McMillan GP, et al. Renal cell carcinoma in relation to cigarette smoking: meta-analysis of 24 studies. Int $J$ Cancer. 2005;114:101-108.

100. Yuan JM, Castelao JE, Gago-Dominguez M, et al. Tobacco use in relation to renal cell carcinoma. Cancer Epidemiol Biomarkers Prev. 1998;5:429-433.

101. Benichou J, Chow WH, McLaughlin JK, et al. Population attributable risk of renal cell cancer in Minnesota. Am J Epidemiol. 1998;148:424-430.

102. Hajjar I, Kotchen TA. Trends in prevalence, awareness, treatment, and control of hypertension in the United States, 1988-2000. JAMA. 2003;290:199-206.

103. Shapiro JA, Williams MA, Weiss NS, et al. Hypertension, antihypertensive medication use, and risk of renal cell carcinoma. Am J Epidemiol. 1999;149:521-530.

104. Grove JS, Nomura A, Severson RK, Stemmermann GN. The association of blood pressure with cancer incidence in a prospective study. Am J Epidemiol. 1991;134:942-947.

105. Schouten LJ, van Dijk BA, Oosterwijk E, et al. Hypertension, antihypertensives and mutations in the Von Hippel-Lindau gene in renal cell carcinoma: results from the Netherlands Cohort Study. J Hypertens. 2005;23:1997-2004.

106. Weikert S, Boeing H, Pischon T, et al. Blood pressure and risk of renal cell carcinoma in the European Prospective Investigation into Cancer and Nutrition. Am J Epidemiol. 2008;167:438-446.

107. Fryzek JP, Poulson AH, Johnsen SP, et al. A cohort study of antihypertensive treatments and risk of renal cell cancer. $\mathrm{Br} J$ Cancer. 2005;92:1302-1306. 
108. Rosenberg L, Stephenson WP, Rao RS, et al. The diagnosis of renal cell cancer in relation to hypertension (United States). Cancer Causes Control. 1998;9:611-614.

109. McLaughlin JK, Blot WJ, Mehl ES, et al. Relation of analgesic use to renal cancer: population-based findings. NCI Monogr. 1985;69:213-215.

110. Derby LE, Jick H. Acetaminophen and renal and bladder cancer. Epidemiology. 1996;7:358-362.

111. Rosenberg L, Rao RS, Palmer JR, et al. Transitional cell cancer of the urinary tract and renal cell cancer in relation to acetaminophen use (United States). Cancer Causes Control. 1998;9:83-88.

112. Gago-Dominguez M, Yuan JM, Castelao JE, et al. Regular use of analgesics is a risk factor for renal cell carcinoma. $\mathrm{Br} J$ Cancer. 1999;81:542-548.

113. Kaye JA, Myers MW, Jick H. Acetaminophen and the risk of renal and bladder cancer in the general practice research database. Epidemiology. 2001;12:690-694.

114. Baigent C, Keech A, Kearney PM, et al. Efficacy and safety of cholesterol-lowering treatment: prospective meta-analysis of data from 90,056 participants in 14 randomized trials of statins. Lancet. 2005;366:1267-1278.

115. Dale KM, Coleman CI, Henyan NN, Kluger J, While CM. Statins and cancer risk: a meta-analysis. JAMA. 2006;295:74-80.

116. Browning DRL, Martin RM. Statins and cancer risk: a systematic review and metaanalysis. Int J Cancer. 2006;120:833-843.

117. Khurana V, Caldito G, Ankem M. Statins might reduce risk of renal cell carcinoma in humans: case-control study of 500,000 veterans. Urology. 2008;71:118-122.

118. Duncan RE, El Sohemy A, Archer MC. Statins and cancer development. Cancer Epidemiol Biomarkers Prev. 2005;14:1897-1898.

119. Karp I, Behlouli H, LeLorier J, Pilote L. Statins and cancer risk. Am J Med. 2008;121:302-309.

120. Blais L, Desgagne A, LeLorier J. 3-Hydroxy-3-methylglutaryl coenzyme A reductase inhibitors and the risk of cancer: a nested case-control study. Arch Intern Med. 2000;160:2363-2368.

121. Kaye JA, Jick H. Statin use and cancer risk in the General Practice Research Database. Br J Cancer. 2004;90:635-637.

122. Graaf MR, Beiderbeck AB, Egberts AC, Richel DJ, Guchelaar HJ. The risk of cancer in users of statins. J Clin Oncol. 2004;22:2388-2394.

123. Coogan PF, Rosenberg L, Strom BL. Statin use and the risk of 10 cancers. Epidemiology. 2007;18:213-219.

124. Farwell WR, Scranton RE, Lawler EV, et al. The association between statins and cancer incidence in a veterans population. J Natl Cancer Inst. 2008;100:134-139.

125. Friedman GD, Flick ED, Udaltsova N, Chan J, Quesenberry CP, Habel LA. Screening statins for possible carcinogenic risk: up to 9 years of follow-up of 361,859 recipients. Pharmacopidemiol Drug Safety. 2008;17:27-36.

126. Wolk A, Lindblad P, Adami HO. Nutrition and renal cell cancer. Cancer Causes Control. 1996;7:5-18.

127. Yuan JM, Gago-Dominguez M, Castelao JE, et al. Cruciferous vegetables in relation to renal cell carcinoma. Int J Cancer. 1998;77:211-216.

128. Hu J, Mao Y, White K, et al. Diet and vitamin or mineral supplements and risk of renal cell carcinoma in Canada. Cancer Causes Control. $2003 ; 14: 705-714$.

129. Lee JE, Giovannucci E, Smith-Warner SA, Spiegelman D, Willett WC, Curhan GC. Intakes of fruits, vegetables, vitamins A, C, and E, and carotenoids and risk of renal cell cancer. Cancer Epidemiol Biomarkers Prev. 2006;15:2445-2452.

130. Bravi F, Bosetti C, Scotti L, et al. Food groups and renal cell carcinoma: a case-control study from Italy. Int J Cancer. 2006;120:681-685.

131. Weikert S, Boeing H, Pischon T, et al. Fruits and vegetables and renal cell carcinoma: findings from the European Prospective Investigation into Cancer and Nutrition (EPIC). Int J Cancer. 2006;118:3133-3139.

132. van Dijk BAC, Schouten LJ, Kiemeney LALM, Goldbohm A, van den Brandt PA. Vegetable and fruit consumption and risk of renal cell carcinoma: results form the Netherlands cohort study. Int J Cancer. 2005; 117:648-654.
133. Lee JE, Spiegelman D, Hunter DJ, et al. Fat, protein, and meat consumption and renal cell cancer risk: a pooled analysis of 13 prospective studies. J Natl Cancer Inst. 2008;100:1695-1706.

134. Breslow NE, Enstrom JE. Geographic correlations between cancer mortality rates and alcohol-tobacco consumption in the United States. J Natl Cancer Inst. 1974;53:631-639.

135. Armstrong B, Doll R. Environmental factors and cancer incidence and mortality in different countries, with special reference to dietary practices. Br J Cancer. 1975;15:617-631.

136. Hinds MW, Kolonel LM, Lee J, Hirohata T. Association between cancer incidence and alcohol/cigarette consumption among five ethnic groups in Hawaii. Br J Cancer. 1980;41:929-940.

137. Schmidt W, De Lint. Causes of death of alcoholics. Q J Stud Alcohol. 1972;33:171-185.

138. Pell S, Alonzo CA. A five-year mortality study of alcoholics. J Occup Med. 1973;15:120-121.

139. Monson RR, Lyon JL. Proportional mortality among alcoholics. Cancer. 1975;36:1077-1079.

140. Jensen OM. Cancer morbidity and causes of death among Danish brewery workers. Int J Cancer. 1979;23:454-463.

141. Adami HO, McLaughlin JK, Hsing AW, et al. Alcoholism and cancer risk: a population-based study. Cancer Causes Control. 1992;3:419-425.

142. Schmidt W, Popham RE. The role of drinking and smoking in mortality from cancer and other causes in male alcoholics. Cancer. 1981;47:1031-1041.

143. Lee JE, Giovannucci E, Smith-Warner SA, Spiegelman D, Willett WC, Curhan GC. Total fluid intake and use of individual beverages and risk of renal cell cancer in two large cohorts. Cancer Epidemiol Biomarkers Prev. 2006;15:1204-1211.

144. Mahabir S, Leitzmann MF, Virtanen MJ, et al. Prospective study of alcohol drinking and renal cell cancer risk in a cohort of Finnish male smokers. Cancer Epidemiol Biomarkers Prev. 2005;14:170-175.

145. Rashidkhani B, Akesson A, Lindblad P, Wolk A. Alcohol consumption and risk of renal cell carcinoma: a prospective study of Swedish women. Int J Cancer. 2005;117:848-853.

146. Lee JE, Hunter DJ, Spiegelman D, et al. Alcohol intake and renal cell cancer in a pooled analysis of 12 prospective studies. J Natl Cancer Inst. 2007;99:801-810.

147. Bagnardi V, Blangiardo M, La Vecchia C, Corrao G. A meta-analysis of alcohol drinking and cancer risk. Br J Cancer. 2001;85:1700-1705.

148. Kabat GC, Navarro Silvera SA, Miller AB, Rohan TE. A cohort study of reproductive and hormonal factors and renal cell cancer risk in women. Br J Cancer. 2007;96:845-849.

149. Zucchetto A, Talamini R, Dal Maso L, et al. Reproductive, menstrual, and other hormone-related factors and risk of renal cell cancer. Int J Cancer. 2008;123:2213-2216

150. Setiawan VW, Kolonel LN, Henderson BE. Menstrual and reproductive factors and risk of renal cell cancer in the multiethnic cohort. Cancer Epidemiol Biomarkers Prev. 2009;18:337-340.

151. Lambe M, Lindblad P, Wuu J, et al. Pregnancy and risk of renal cell cancer: a population-based study in Sweden. $\mathrm{Br} J$ Cancer. 2002;86:1425-1429.

152. Selikoff IJ, Hammond EC, Seidman H. Mortality experience of insulation workers in the United States and Canada, 1943-1976. Ann NY Acad Sci. 1979;330:91-116.

153. Enterline PE, Hartley J, Henderson V. Asbestos and cancer: a cohort followed up to death. Br J Ind Med. 1987;44:396-401.

154. Sali D, Boffetta P. Kidney cancer and occupational exposure to asbestos: a meta-analysis of occupational cohort studies. Cancer Causes Control. 2000;11:37-47.

155. McLaughlin JK. Renal cell cancer and exposure to gasoline: a review. Environ Health Perspect Suppl. 1993;101(Suppl 6):111-114.

156. Lynge E, Andersen A, Nilsson R, et al. Risk of cancer and exposure to gasoline vapors. Am J Epidemiol. 1997;145:449-458.

157. International Agency for Research on Cancer. Occupational exposures in petroleum refining; crude oil and major petroleum fuels. IARC Monogr Eval Carcinog Risks Hum. 1989;45:39-117. 
158. Wong O, Harris F, Smith TJ. Health effects of gasoline exposure. II. Mortality patterns among petroleum refinery workers. Environ Health Perspect. 1993;101(Suppl 6):63-76.

159. Wong O, Trent L, Harris F. Nested case-control study of leukemia, multiple myeloma and kidney cancer in a cohort of petroleum workers exposed to gasoline. Occup Environ Med. 1999;56:217-221.

160. Rushton L. The UK oil refinery and distribution centre studies: a 39-year follow-up. Environ Health Perspect. 1993;101(Suppl 6):77-84.

161. Schnatter AR, Katz AM, Nicolich MJ, et al. A retrospective mortality study among Canadian petroleum marketing and distribution workers. Environ Health Perspect. 1993;101(Suppl 6):85-99.

162. McCredie M, Stewart JH. Risk factors for kidney cancer in New South Wales: IV. Occupation. Br J Ind Med. 1993;50:349-354.

163. Gamble JF, Pearlman ED, Nicolich MJ. A nested case-control study of kidney cancer among refinery/petrochemical workers. Environ Health Perspect. 1996;104:642-650.

164. Lohi J, Kyyronen P, Kauppinen T, Kujala V, Pukkala E. Occupational exposure to solvents and gasoline and risk of cancers of the urinary tract among Finnish workers. Am J Ind Med. 2008;51:668-672.

165. Lewis RJ, Schnatter AR, Drummond I, et al. Mortality and cancer morbidity in a cohort of Canadian petroleum workers. Occup Environ Med. 2003;60:918-928.

166. Swenberg JA, Lehman-McKeeman LD. $\alpha_{2}$-Urinary globulin-associated nephropathy as a mechanism of renal tubule cell carcinogenesis in male rats. In: Capen CC, Dybing E, Rice JM, et al. editors. Species differences in thyroid, kidney and urinary bladder carcinogenesis. IARC Scientific Publication No. 147. Lyon, France: International Agency for Research on Cancer; 1999. p. 95-117.

167. Henschler D, Vamvakas S, Lammert M, et al. Increased incidence of renal cell tumors in a cohort of cardboard workers exposed to trichloroethylene. Arch Toxicol. 1995;69:291-299.

168. Vamvakas S, Bruning T, Thomasson B, et al. Renal cell cancer correlated with occupational exposure to trichloroethene. $J$ Cancer Res Clin Oncol. 1998;124:374-382.

169. Bruning T, Pesch B, Wiesenhutter B, et al. Renal cell cancer risk and occupational exposure to trichloroethylene: results of a consecutive casecontrol study in Arnsberg, Germany. Am J Ind Med. 2003;43:274-285.

170. McLaughlin JK, Blot WJ. A critical review of epidemiology studies of trichloroethylene and perchloroethylene and risk of renal cell cancer. Int Arch Occup Environ Health. 1997;70:222-231.

171. Green LC, Lash TL. Re: "Renal cell cancer correlated with occupational exposure to trichloroethylene." J Cancer Res Clin Oncol. $1999 ; 125: 430-432$.
172. Cherrie JW, Kromhout H, Semple S. The importance of reliable exposure estimates in deciding whether trichloroethylene can cause kidney cancer. J Cancer Res Clin Oncol. 2001;127:400-404.

173. Blair A, Hartge P, Stewart PA, et al. Mortality and cancer incidence of aircraft maintenance workers exposed to trichloroethylene and other organic solvents and chemicals: extended follow up. Occup Environ Med. 1998;55:161-171.

174. Boice JD, Marano DE, Fryzek JP, et al. Mortality among aircraft manufacturing workers. Occup Environ Med. 1999;56:581-597.

175. Raaschou-Nielsen O, Hansen J, McLaughlin JK, et al. Cancer risk among workers at Danish companies using Trichloroethylene: a cohort study. Am J Epidemiol. 2003;158:1182-1192.

176. Wong O. Carcinogenicity of trichloroethylene: an epidemiologic assessment. Clin Occup Environ Med. 2004;4:557-589.

177. Brauch H, Weirich G, Hornauer MA, Störkel S, Wöhl T, Brüning T. Trichloroethylene exposure and specific somatic mutations in patients with renal cell carcinoma. J Natl Cancer Inst. 1999;91: 854-861.

178. Brauch H, Weirich G, Klein B, Rabstein S, Bolt H, Brüning T. VHL mutations in renal cell cancer: does occupational exposure to trichloroethylene make a difference? Toxicol Lett. 2004;151: 301-310.

179. Charbotel B, Gad S, Caïola D, et al. Trichloroethylene exposure and somatic mutations of the VHL gene in patients with renal cell carcinoma. J Occup Med Toxicol. 2007;2:13.

180. Schraml P, Zhaou M, Richter J, et al. Analysis of renal tumors in trichloroethylene-exposed workers by comparative genomic hybridization and DNA sequencing analyses. Verh Dtsch Ges Path. 1999;83:218-224.

181. van Houweligen KP, van Dijk BAC, Hulsbergen-van de Kaa CA, et al. Prevalence of von Hippel-Lindau gene mutations in sporadic renal cell carcinoma: results of the Netherlands cohort study. BMC Cancer. 2005;5:57.

182. Stewart JH, Buccianti G, Agodoa L, et al. Cancers of the kidney and urinary tract in patients on dialysis for end-stage renal disease: analysis of data from the United States, Europe, and Australia and New Zealand. J Am Soc Nephrol. 2003;14:197-207.

183. Satoh S, Tsuchiya N, Habuchi T, et al. Renal cell and transitional cell carcinoma in a Japanese population undergoing maintenance dialysis. J Urol. 2005;174:1749-1753.

184. Neuzillet Y, Lay F, Luccioni A, et al. De novo renal cell carcinoma of native kidney in renal transplant recipients. Cancer. 2005;103: 251-257. 
